\title{
Trichomycterus maracaya, a new catfish from the upper rio Paraná, southeastern Brazil (Siluriformes: Trichomycteridae), with notes on the T. brasiliensis species-complex
}

\author{
Flávio A. Bockmann* and Ivan Sazima**
}

Trichomycterus maracaya, a new species of Trichomycteridae, is described from a streamlet in the upper rio Paraná, Poços de Caldas, State of Minas Gerais, southeastern Brazil. The following putative autapomorphies distinguishes T. maracaya from congeneric species: 1) row of lateral blotches not forming a stripe at any phase during ontogeny; 2) superficial layer of pigmentation of juveniles and large (presumably adults) specimens consisting solely of scattered chromatophores. Furthermore, the new species is characterized by a combination of yellow ground color in life and mottled pattern formed by small to medium-sized, brown, irregularly-coalescent, well-defined deeper-lying blotches, and more superficial dots on the body. Trichomycterus maracaya is assigned to the T. brasiliensis species-complex (which includes T. brasiliensis, T. iheringi, T. mimonha, T. potschi, T. vermiculatus, and several undescribed species apparently endemic to the main river basins draining the Brazilian Shield) based on the presence of: 1) blotches in four longitudinal rows of deeper-lying pigmentation on the trunk large, horizontally-elongated, and well-defined; 2) pectoral fin with I+5-6 rays; 3 ) separation between the anterior and posterior cranial fontanels by the primordial epiphyseal cartilaginous bar being present only in larger specimens; and 4) pelvic-fin bases very close to each other, sometimes in contact.

Trichomycterus maracaya, uma espécie nova de Trichomycteridae, é descrita de exemplares obtidos num riacho do alto rio Paraná, Poços de Caldas, Estado de Minas Gerais, sudeste do Brasil. As seguintes supostas autapomorfias distinguem T. maracaya de outras espécies do gênero: 1) fileira de manchas laterais que não se fundem em listra em nenhuma fase da ontogenia; 2) camada superficial de pigmentação de juvenis e exemplares maiores (supostamente adultos) consistindo somente de cromatóforos dispersos. Além disso, a nova espécie é caracterizada pela combinação de coloração de fundo amarela em vida e padrão mosqueado, formado por manchas castanhas pequenas a médias bem definidas e aglutinadas irregularmente, situadas em camada mais profunda do tegumento, além de pontos mais superficiais espalhados pelo corpo. Trichomycterus maracaya é aqui designada ao complexo de espécies T. brasiliensis (que inclui T. brasiliensis, T. iheringi, T. mimonha, T. potschi e T. vermiculatus, além de várias espécies não descritas, aparentemente endêmicas às bacias dos rios principais que drenam o Escudo Brasileiro), com base em: 1) manchas horizontalmente alongadas, grandes e bem definidas, situadas mais profundamente no tegumento e dispostas em quatro fileiras longitudinais no corpo; 2) nadadeira peitoral com I+5-6 raios; 3) separação entre as fontanelas cranianas anterior e posterior, por barra cartilaginosa primordial da epífise, apenas nos exemplares maiores; e 4) bases das nadadeiras pélvicas muito próximas uma da outra, por vezes em contato.

Key words: Pencil catfish, Ostariophysi, Endemic, Neotropics.

\section{Introduction}

The catfish family Trichomycteridae includes about 200 species of small-sized fishes currently allocated to eight subfamilies (de Pinna, 1998). Trichomycterids are mostly known for the parasitic habits of species in the subfamilies Stegophilinae and Vandelliinae. However, most of species of the Trichomycteridae are non-parasitic and feed on aquatic or terrestrial (allochthonous) invertebrates (de Pinna, 1998).

The largest group among the non-parasitic component of the family is the Trichomycterinae, whose species dwell in headwaters and small, cold clear water streams running over stony beds (de Pinna, 1998). Due to the patchy distribution of their habitats, trichomycterines generally have restricted geographic distributions and, thus, display a high level of endemism (e.g., Costa, 1992; de Pinna, 1992a; Bizerril, 1994;

\footnotetext{
*Laboratório de Ictiologia de Ribeirão Preto, Departamento de Biologia, FFCLRP, Universidade de São Paulo, Av. dos Bandeirantes 3900 , 14040-901 Ribeirão Preto, São Paulo, Brazil. e-mail: fabockmann@ ffclrp.usp.br

**Departamento de Zoologia and Museu de História Natural, Caixa Postal 6109, Universidade Estadual de Campinas, 13083-970 Campinas, São Paulo, Brazil. e-mail: isazima@unicamp.br
} 


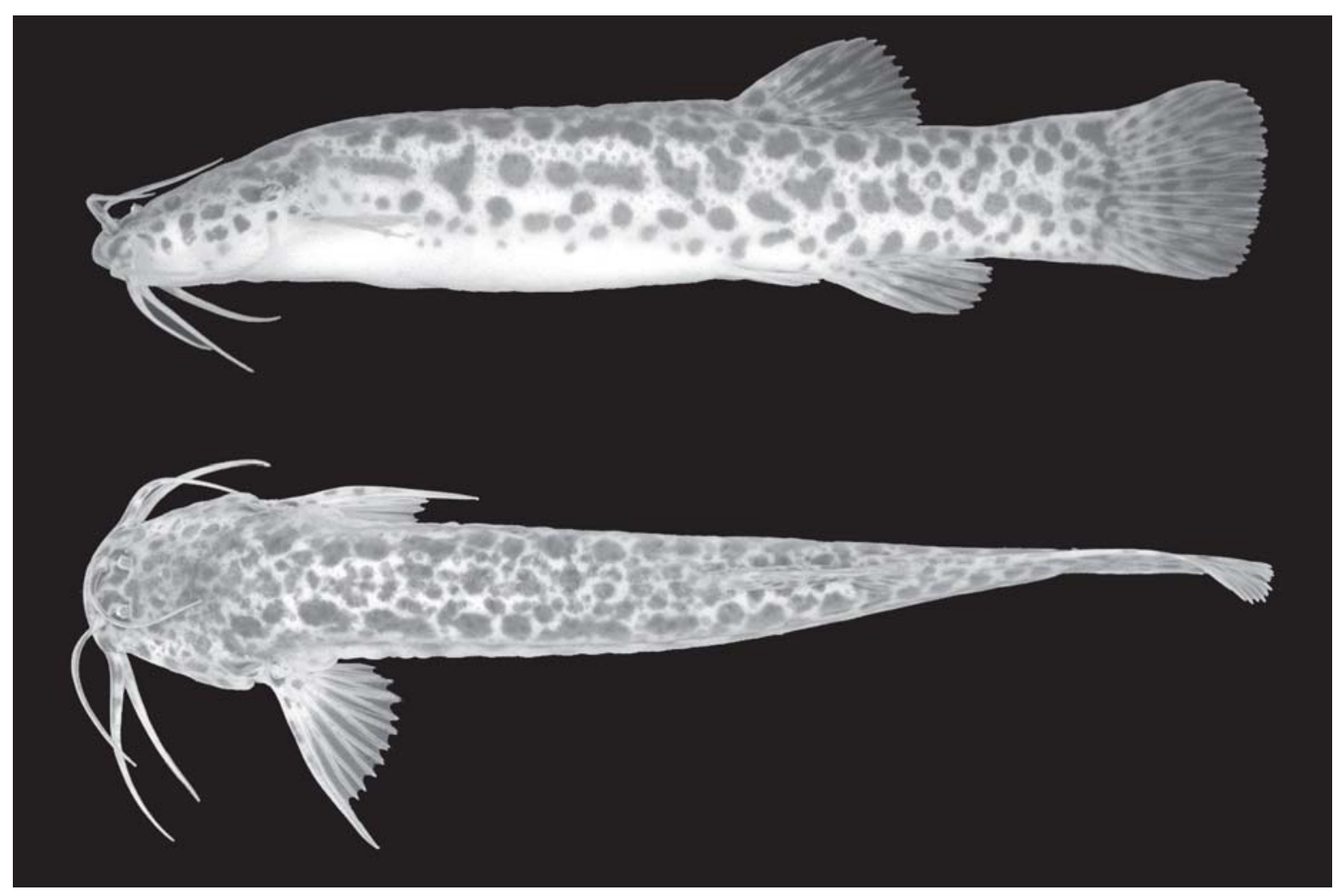

Fig. 1. Trichomycterus maracaya. (ZUEC 6137), $48.8 \mathrm{~mm}$ SL, holotype; Morro do Ferro, município de Poços de Caldas, Minas Gerais, southeastern Brazil.

Barbosa \& Costa, 2003). The few wide-ranging "species" such as Trichomycterus brasiliensis Lütken (sensu Britski et al., 1986; Bizerril, 1994; Casatti \& Castro, 1998) most probably are complexes of similar species difficult to tell apart, a common trend within the genus (de Pinna, 1998).

Trichomycterus is a species-rich and widely distributed genus of Trichomycteridae, with about 90 nominal species ranging from Central to South America on both sides of the Andes (de Pinna \& Wosiacki, 2003), and no description of a species within the genus compares it with more than a handful of species. This is due not only to the overwhelming and poorly characterized species diversity, but also to the long and complicated taxonomic history with available names with doubtful applicability due to poor original descriptions, as well as long preserved type specimens with the consequent loss of several taxonomically-useful features (de Pinna, 1998). The upper rio Paraná, the portion of the rio Paraná basin upriver from the former Sete Quedas Falls (Castro \& Casatti, 1997) is characterized by the endemism of its ichthyofauna particularly in the case of small, headwater-dwelling species (e.g., Castro \& Menezes, 1998). The species of Trichomycterus, given their small size and patchy distribution, would be expected to demonstrate that pattern. We describe herein a new species from the upper rio Paraná, caught in a streamlet at the Morro do Ferro, Poços de Caldas, Minas Gerais, southeastern Brazil, apparently endemic to a small portion of the rio Pardo basin.

\section{Material and Methods}

Morphometric measurements were made point-to-point with digital calipers to the nearest $0.1 \mathrm{~mm}$. Methodology and terminology for measurements and counts follow de Pinna (1992a, b) with the addition of: 1) total length, 2) length of first and second unbranched and segmented dorsal-fin rays, 3) length of first and second branched dorsal-fin rays, 4) length of the first through third rays of the pectoral and pelvic fins, 5) body width (taken at dorsal-fin origin), 6) cleithral width, 7) eye diameter (taken at horizontal length of eye), 8) distance between snout tip and posterior nare (distance between most anterior tip of snout and anterior rim of posterior nare), 9) intranarial length (distance between adjacent anterior and posterior nares), and 10) anterior and posterior internarial widths (distances between contralateral anterior and posterior nares, respectively). Height of dorsal, and length of pectoral and pelvic fins are usually measured along their longest axis; however, these measurements do not necessarily involve homologous points due to the different fin shapes. Therefore, to estimate the size variation of dorsal, pectoral, and pelvic fins in a comparable sense, lengths of first three rays of those fins were independently measured. Morphometric data and fin rays counts of bilateral structures or parts were taken from the left side of the specimens. The total caudal-fin rays for large specimens could not be accurately counted because of the very thick caudal-fin fold. All types specimens were measured. The number of 


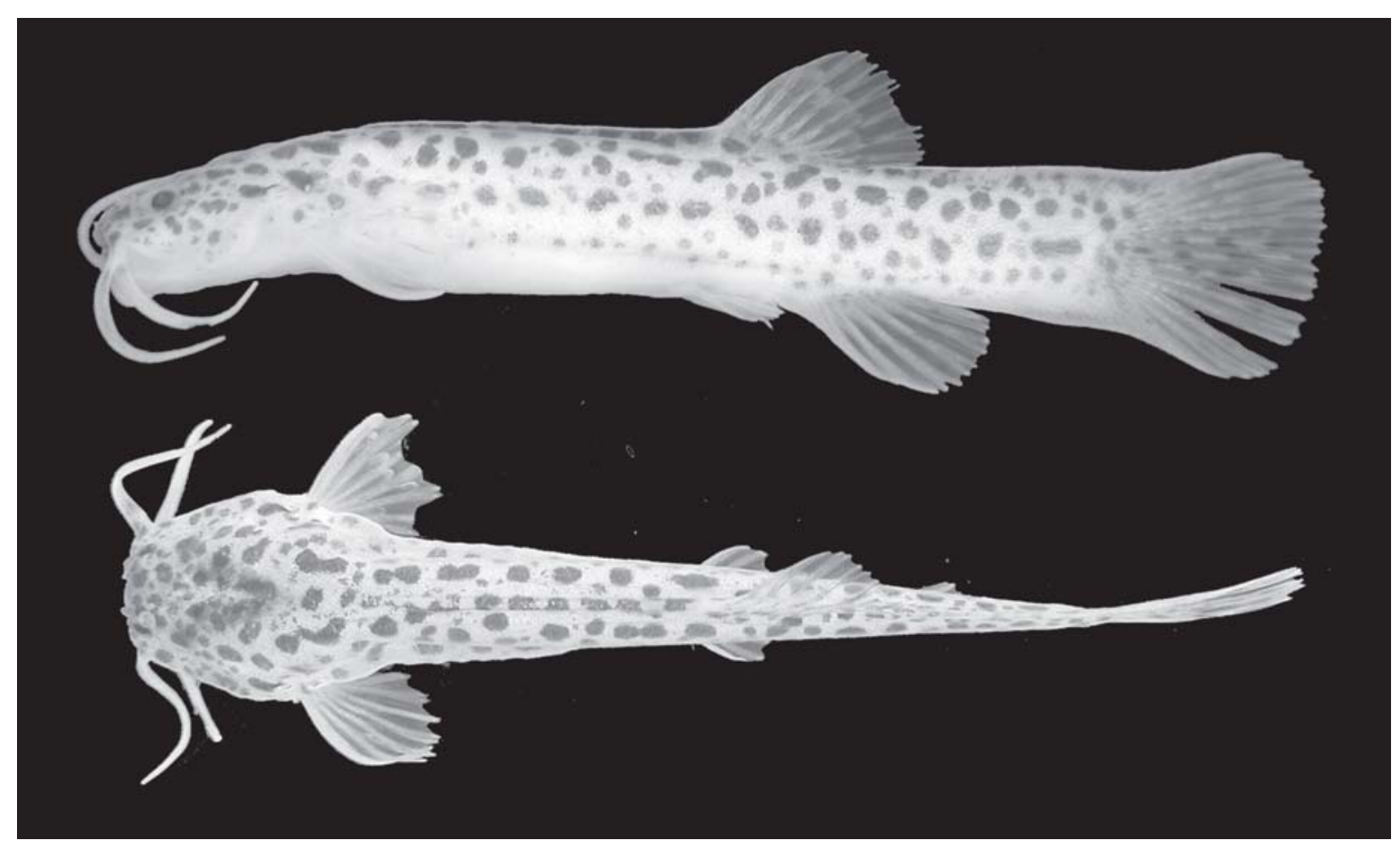

Fig. 2. Trichomycterus maracaya, n. sp. (ZUEC 6138), juvenile $22.8 \mathrm{~mm}$ SL, paratype.

specimens tallied in counts is presented in parentheses. An asterisk indicates the count for the holotype in variable meristics. Data on fin position and osteology were obtained from two c\&s paratypes following the procedure of Taylor \& Van Dyke (1985). In fin-ray counts, the anterior unbranched and unsegmented rays are represented by lower case Roman numerals, unbranched segmented rays by upper case Roman numerals, and branched segmented rays by Arabic numerals. The most medial ray of the pectoral fin and posteriormost dorsal- and anal-fin rays were counted as branched segmented rays, in all instances, in order to express their serial homologies. Vertebral counts included all vertebrae (including the first five vertebrae modified into Weberian complex), with the compound caudal centrum (PU1+U1) counted as one element (Lundberg $\&$ Baskin, 1969). Most of the nomenclature for bones followed de Pinna (1989), except for the lacrimal and supraoccipital that are here named antorbital and parieto-supraoccipital, respectively, in order to express their correct homologies ( $c f$. Arratia, 1998; FAB, pers. obs.). Terminology for cephalic laterosensory canals follows Northcutt (1989). Nomenclature and homologies for supraorbital and infraorbital sensory canal systems follow Arratia \& Huaquin (1995). Morphological data for T. nigricans Valenciennes, T. paolence (Eigenmann), T. potschi Barbosa \& Costa, T. triguttatus (Eigenmann), and T. vermiculatus (Eigenmann) are based on literature (Eigenmann, 1918; Arratia, 1998; Barbosa \& Costa, 2003). Institutional abbreviations follow Leviton et al. (1985) with addition of LBP (Laboratório de Biologia de Peixes, Universidade Estadual Paulista, Botucatu, Brazil) and LIRP (Laboratório de Ictiologia de Ribeirão Preto, Universidade de São Paulo, Ribeirão Preto, Brazil).

\section{Trichomycterus maracaya, new species}

Figs. 1-8

Holotype. ZUEC 6137, 48.8 mm SL; unsexed; Brazil, Minas Gerais, Poços de Caldas, rio Pardo basin, unnamed streamlet at the foothill of the Morro do Ferro (about 46 $31^{\prime} 50^{\prime \prime} \mathrm{S}$, 21 46 '45”W); C. F. B. Haddad \& I. Sazima; 6 February 2003.

Paratypes. 17 specimens: LIRP 4381, 3, 26.7-51.3 mm SL, 1 c\&s, 43.9 mm SL; MCP 34575, 2, 30.7-31.6 mm SL; MNRJ 25872, 2, 31.8-33.6 mm SL; MZUSP 83357, 2, 29.6-41.9 mm SL; ZUEC 6136, 3, 24.1-45.6 mm SL;ZUEC 6138, 2, 22.8-48.1 mm SL, 1 c\&s, $32.5 \mathrm{~mm}$ SL; all collected with the holotype; ZUEC 4115, 1, 45.9 mm SL; same locality as holotype; A. J. Cardoso, C. F. B. Haddad \& G. U. Andrade; 8 January 1981.

Diagnosis. Trichomycterus maracaya, along with T. brasiliensis, T. iheringi (Eigenmann), T. mimonha Costa, T. potschi, and T. vermiculatus, are members of the Trichomycterus brasiliensis species-complex, based on the possession of the following apomorphic characters unique in Trichomycterus: four longitudinal rows of well-defined blotches formed by very dense concentration of dark chromatophores in the deeper layer of skin ( $v s$. four rows faint, with limits of blotches poorly-defined); and pectoral fin with $\mathrm{I}+5-6$ rays ( $v s$. usually $\mathrm{I}+7-8)$. Members of this putative clade (except for $T$. iheringi) may be further distinguished from other species of Trichomycterus in having the bases of the pelvic fins very close to each other, sometimes in contact ( $v s$. the pelvic-fin bases very spaced). Additionally, T. maracaya differs from the remaining species of Trichomycterus 


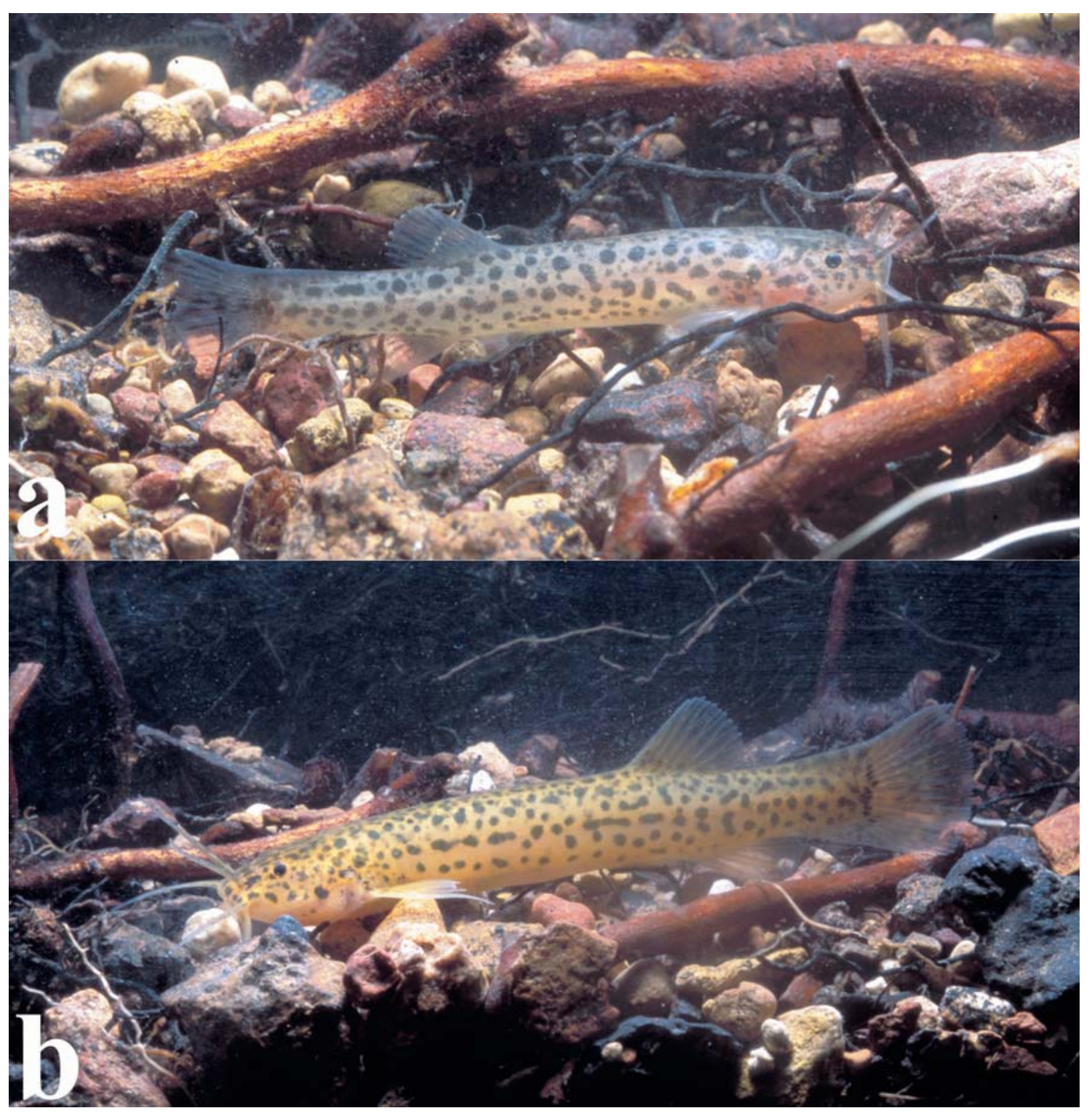

Fig. 3. Trichomycterus maracaya, n. sp. (ZUEC 6136), paratypes photographed in field aquarium shortly after collection. a, juvenile $24.1 \mathrm{~mm} \mathrm{SL}$; $\mathbf{b}$, presumed adult $45.6 \mathrm{~mm} \mathrm{SL}$.

(except T. brasiliensis and T. potschi) in retaining the primordial epiphyseal cartilaginous bar separating the anterior and posterior cranial fontanels even in larger individuals ( $v s$. having the osseous epiphyseal bar separating the anterior and posterior cranial fontanels appearing early in the ontogeny). Furthermore, $T$. maracaya is distinguished from other species of the $T$. brasiliensis species-complex, and from all congeners, in the following putative autapomorphies: 1) row of blotches on lateral surface not forming a lateral stripe in any stage during ontogeny (vs. lateral row of blotches, when present, forming a lateral stripe usually conspicuous early in ontogeny); 2) superficial layer of pigmentation of juveniles and larger, presumably adult, specimens formed by scattered chromatophores ( $v s$. superficial layer of pigmentation, when present, of larger specimens formed by dense pattern of chromatophores often overlaying the larger blotches of the lower layer of pigmentation).

Description. Morphometric data for type series presented in Table 1. Dorsal profile of body sloped from tip of snout to anterior portion of trunk and approximately straight from that point to base of caudal fin (Figs. 1-3). Convexity of trunk more pronounced in larger individuals. Ventral body profile approximately straight to slightly convex from mouth to insertion of pelvic fin; slightly concave from end of base of pelvic fin to caudal fin. Crosssection of body in trunk region approximately oval, becoming gradually more compressed transversely posterior to base of dorsal fin. Caudal peduncle strongly compressed. Axillary gland with small pore. Urogenital and anal openings on vertical through base of first or second branched dorsal-fin rays.

Head wide and depressed, slightly longer than broad (Fig. 
4). Eyes small, orbital rim not free except for discrete ventral invagination. Skin covering eye thin and translucent. Anterior nostril small, surrounded by fleshy tube-shaped flap of integument. Posterior nostril located approximately midway between anterior nostril and anterior orbital rim, and surrounded by raised fleshy flap, except posteriorly. Mouth inferior. Lower lip with conspicuous lateral fleshy lobes medial to origin of rictal barbels. Nasal barbel originating on posterolateral portion of integumentary flap around anterior nostril; tips of barbel reaching base of pectoral fin. Maxillary barbel extending to posterior border of pectoral-fin base. Rictal barbel shorter than maxillary barbel; tip reaching pectoral-fin base. Barbels progressively tapering distally. Opercular patch of odontodes small and elliptical. Interopercular patch of odontodes narrow, elongate and bearing conspicuous posterior projections but with anterior process very short. Interopercular with seven or eight odontodes in the smaller c\&s specimen (32.5 mm SL) and 12-14 in the larger c\&s specimen (43.9 $\mathrm{mm} \mathrm{SL})$. Opercle with 20 odontodes in the smaller specimen ( $32.5 \mathrm{~mm} \mathrm{SL})$ and 26 odontodes in the larger specimen (43.9 mm SL). Odontodes on both opercle and interopercle gradually increasing in size posteriorly. Tips of larger and posterior odontodes of opercle curved dorsomedially. Branchial membranes thick, united to isthmus only anteriorly and forming small free fold across isthmus. Branchiostegal rays hardly visible through thick skin.

Anterior cornua of mesethmoid with slight anterior concavity (Fig. 5). Anterior fontanel restricted to small cuneiform opening situated immediately anterior to epiphyseal bar. Epiphyseal bar entirely cartilaginous, except for limited, medially-directed bony projection of frontals. Posterior cranial fontanel long and relatively broad between frontals and extending into parieto-supraoccipital. Antorbital short and anteriorly expanded. Tendon-bone supraorbital rod-like, approximately twice as long as antorbital. Anterior portion of sphenotic laterally directed in dorsal view. Sphenotic, prootic, and pterosphenotic entirely fused to each other. Vomer arrowshaped, with long posterior process. Parasphenoid with long and pointed posterior process that reaches posteromedian region of basioccipital. Anterior portion of Weberian complex fused to basioccipital. Weberian capsule with reduced lateral opening that is much smaller than lateral profile of capsule.

Premaxilla with 4 rows of conical teeth; anteriormost row with 12-14 teeth. Maxilla large, boomerang-shaped, and slightly shorter than premaxilla. Lower jaw with 3 rows of conical teeth, smaller c\&s specimen (32.5 mm SL) with 11 teeth in most external row, and larger c\&s specimen (43.9 mm SL) with 13-14 teeth in most external row.

Metapterygoid laminar and very large (Fig. 6). Hyomandibula with conspicuous membranous outgrowth on its anterior margin. Articulation between metapterygoid and quadrate via anterior cartilage block only. Small, somewhat triangular preopercle sutures with ventral margins of both quadrate and hyomandibula.

Hyoid arch with large ventral hypohyal, elongate anterior ceratohyal, and approximately short triangular posterior

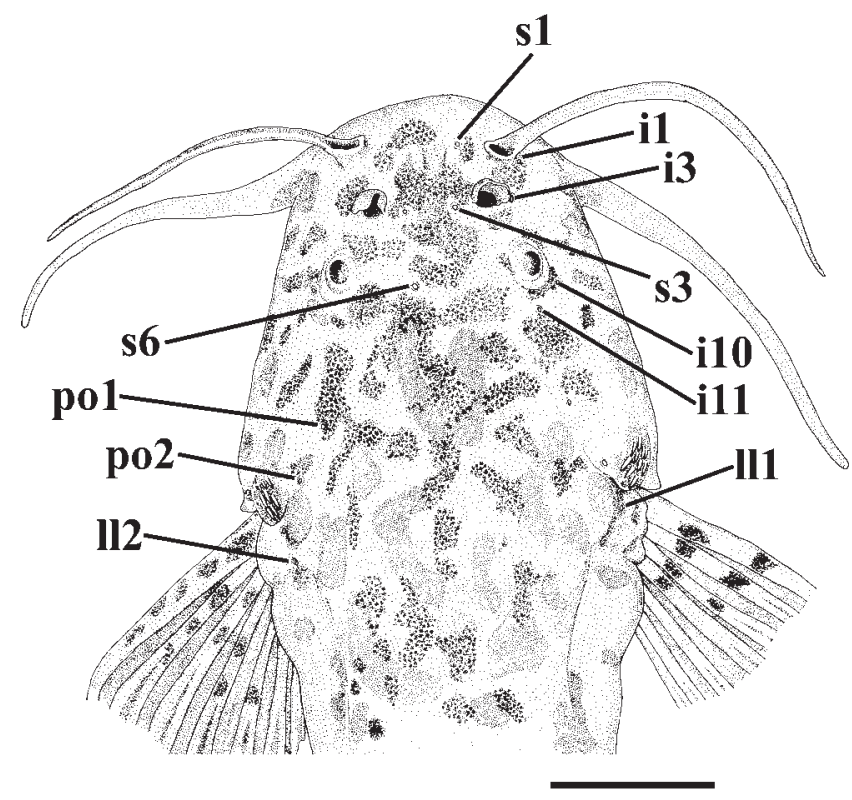

Fig. 4. Head of Trichomycterus maracaya in dorsal view (LIRP 4381), $51.3 \mathrm{~mm}$ SL, paratype, showing pattern composed of two-layered blotches and spots (densely packed lower layer drawn as regularly spaced lighter dots, and loosely grouped upper layer drawn as irregularly spaced darker dots). Abbreviations: i1, infraorbital sensory branch 1; i3, infraorbital sensory branch 3; i10-11, infraorbital sensory branches 10 and 11; ll1-2, lateral line sensory branches 1 (supracleithral sensory branch) and 2; po1-2, postotic sensory branches 1 and 2; s1, supraorbital sensory branch 1; s3, supraorbital sensory branch 3; s6, supraorbital sensory branch 6 (epiphyseal branch). Scale bar $=4 \mathrm{~mm}$.

ceratohyal (Fig. 7). Seven branchiostegal rays (1 specimen with anterior vestigial nodular ray not considered) articulated with hyoid arch: 2 with posteroventral margin of anterior ceratohyal, 1 with mesoventral margin of posterior ceratohyal, and 4 with cartilage between these bones. Branchiostegal rays 3-5 distally expanded and notched. Dorsal hypohyal and interhyal absent.

Urohyal with expanded anterior head, elongate lateral processes, and sharp and moderately short posterior process. Lateral processes of urohyal distally pointed. Basibranchial 1 absent. Basibranchials 2 and 3 with cartilaginous caps at their anterior and posterior tips, and connected to each other forming long rod (Fig. 8). Anterior tip of basibranchial axis extending to level of hypobranchials 1 , not reaching dorsal surface of urohyal keel, with posterior tip situated immediately in front of anteromedial region of contralateral hypobranchials 3. Ossification of basibranchial 2 nearly as long as bony portions of basibranchial 3 and hypobranchial 1. Basibranchial 4 completely cartilaginous, represented by a hexagonal plate. Basibranchial 4 bordered anteriorly by hypobranchials 3 , laterally by cartilaginous heads of ceratobranchials 4 , and posteriorly by cartilaginous heads of ceratobranchials 5. Hypobranchial 1 rod-like, with cartilage only 


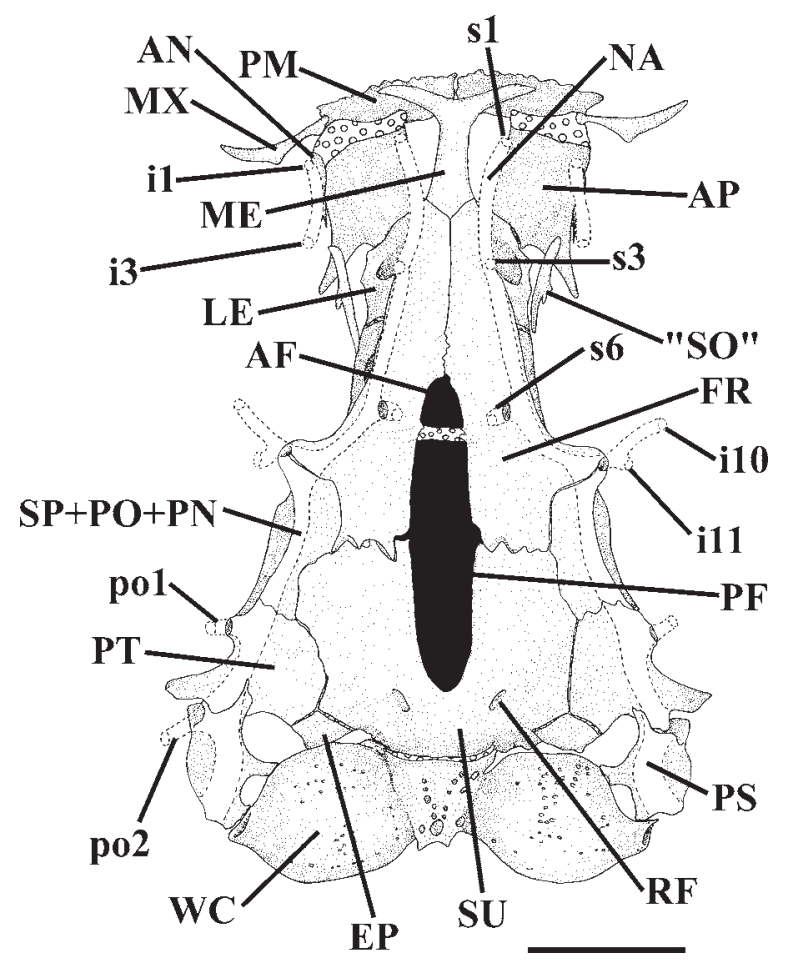

Fig. 5. Cranium and Weberian complex of Trichomycterus maracaya (LIRP 4381), 43.9 mm SL, paratype. Dorsal view. Abbreviations: AF, anterior fontanel; AN, antorbital; AP, autopalatine; EP, epioccipital; FR, frontal; LE, lateral ethmoid; i1, infraorbital sensory branch 1; i3, infraorbital sensory branch 3; i10-11, infraorbital sensory branches 10 and 11; ME, mesethmoid; MX, maxilla; NA, nasal; PF, posterior fontanel; PM, premaxilla; po1-2, postotic sensory branches 1 and 2; PS, posttemporosupracleithrum; PT, pterotic; s1, supraorbital sensory branch $1 ; \mathbf{s 3}$, supraorbital sensory branch 3; s6, supraorbital sensory branch 6 (epiphyseal branch); RF, foramen for ramus lateralis accessorius facialis; "SO", tendon-bone supraorbital; SP+PO+PN, sphenoticprootic-pterosphenoid complex bone; SU, parietosupraoccipital; WC, Weberian capsule. Scale bar $=2 \mathrm{~mm}$.

in its proximal and distal tips, and without uncinate process on its anterodistal portion. Hypobranchial 2 elongate, approximately trapezoidal, mostly cartilaginous except for pointed, anterolaterally-oriented, process on its anterodistal region. Hypobranchial 3 trapezoidal, closely positioned relative to its counterpart, mostly cartilaginous except for pointed, anterolaterally-oriented, process on its anterodistal region. Hypobranchial 4 absent. Five slightly curved and mostly ossified ceratobranchials present; with cartilage present only at their extremities. Proximal portion of ceratobranchial 2 with concavity at its posterior margin, which is posteriorly limited by pointed, mesially directed, process. Proximal portion of ceratobranchial 3 with shallow concavity at its posterior margin. Ceratobranchial 5 expanded posteromedially to support patch of fine conical teeth dorsally, arranged in 2-4 rows, with the teeth of most mesial row

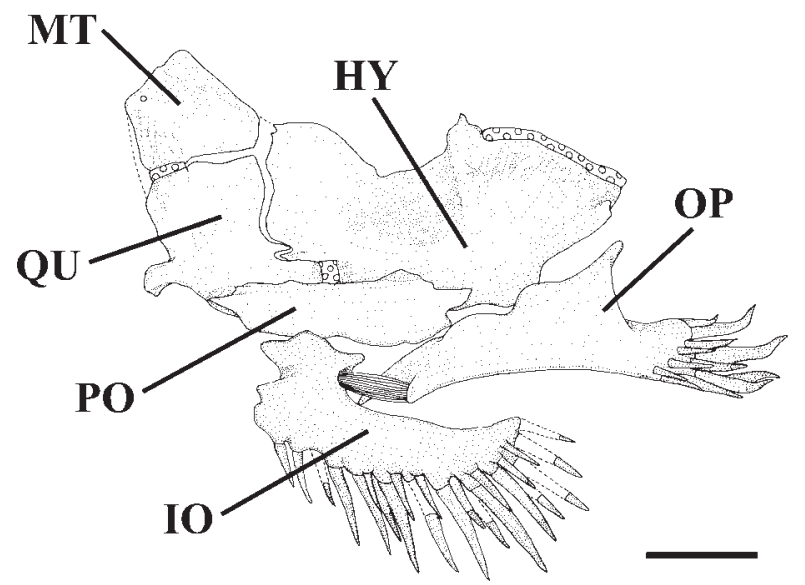

Fig. 6. Left suspensorium and opercular series of Trichomycterus maracaya (LIRP 4381), $43.9 \mathrm{~mm}$ SL, paratype. Lateral view. Abbreviations: HY, hyomandibula; IO, interopercle; MT, metapterygoid; OP, opercle; PO, preopercle; QU, quadrate. Scale bar $=1 \mathrm{~mm}$.

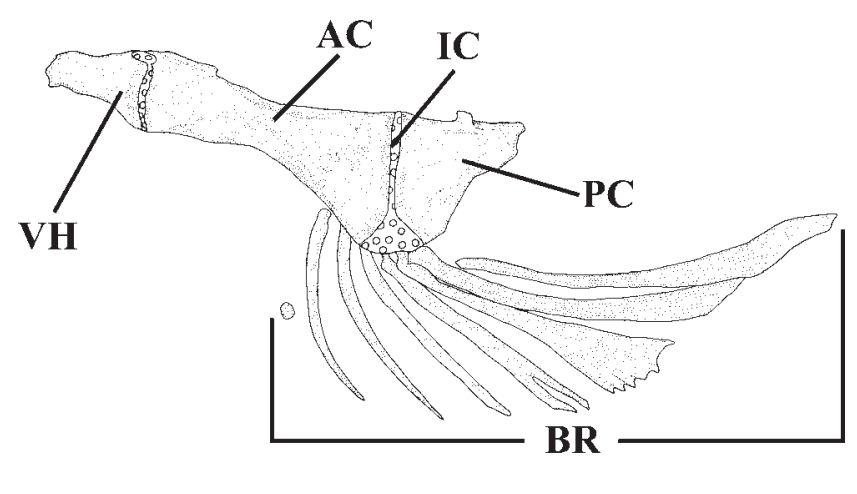

Fig. 7. Left hyoid arch of Trichomycterus maracaya (LIRP 4381), 43.9 mm SL, paratype. Lateral view. Abbreviations: AC, anterior ceratohyal; BR, branchiostegal rays; IC, interceratohyal cartilage; $\mathbf{P C}$, posterior ceratohyal; VH, ventral hypohyal. Scale bar $=1.5 \mathrm{~mm}$.

distinctly larger; 20-26 teeth in smaller specimen ( $32.5 \mathrm{~mm} \mathrm{SL}$ ) and 27-30 teeth in larger specimen (43.9 mm SL). Five epibranchials, first 3 rod-like and largely ossified except at tips. Anterior margin of epibranchial 1 with noticeable elongate uncinate process. Anterior border of epibranchial 2 with blunt process. Posterior margin of epibranchial 3 with robust uncinate process. Epibranchial 4 with rectangular aspect, produced by broad anterior and posterior crests. Epibranchial 5 curved, completely cartilaginous, and situated medial to distal cartilaginous head of ceratobranchial 4 , and reaching distal cartilaginous head of ceratobranchial 5. Pharyngobranchials 1 and 2 absent. Pharyngobranchial 3 elongate, rod-like, with shallow medial lamina, and with lateral margin smooth. Pharyngobranchial 4 well ossified and elongate. Neomorphic cartilaginous nodule, usually located near inner tips of 


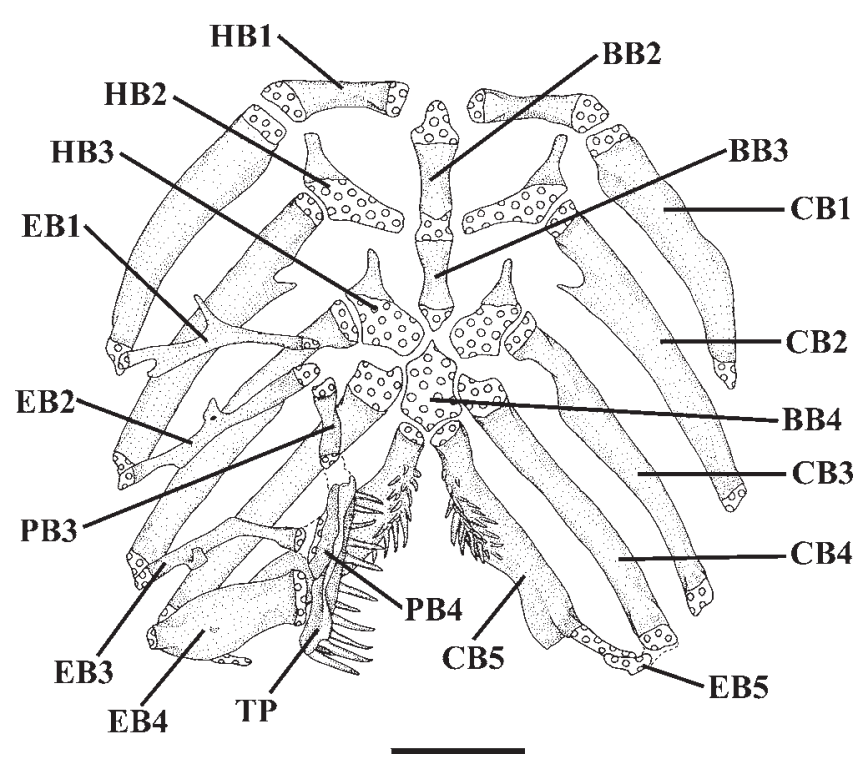

Fig. 8. Branchial skeleton of Trichomycterus maracaya (LIRP 4381), $43.9 \mathrm{~mm}$ SL, paratype. Dorsal view. Dorsal elements of right gill arches and gill rakers not shown. Abbreviations: BB2-4, basibranchials 2 to 4 ; CB1-5, ceratobranchials 1 to 5; EB1-5, epibranchials 1 to 5; HB1-3, hypobranchials 1 to 3; PB3-4, pharyngobranchials 3 and 4; TP, tooth plate. Scale bar $=1 \mathrm{~mm}$.

epibranchials 1 and 2 and anterior tip of pharyngobranchial 3, absent. Large, elongate upper pharyngeal tooth plate situated immediately posterior to posterior extremity of pharyngobranchial 3 , ventral to pharyngobranchial 4 , and medial to tips of epibranchials 3 and 4 . Upper pharyngeal tooth plate with mesial margin plicate, ventrally supporting patch of fine conical teeth, arranged in 2-4 rows, with 4-5 most posterior teeth of main row very large and curved at their tips; $27-28$ teeth in smaller specimen $(32.5 \mathrm{~mm}$ SL) and 29-34 teeth in larger specimen (43.9 mm SL).

Pectoral-fin rays I+6 $(17 *)$, rarely I+7 (1). Fin well-developed, rounded, and thick, with insertion immediately posterior to opercular membrane. Tip of first unbranched pectoral-fin ray prolonged (filamentous portion of ray 20-30\% of total ray length in larger individuals and proportionally shorter in smaller individuals). Muscular base of pectoral fin broad, its breadth about $60 \%$ of mouth width.

Pelvic-fin rays I+4 (18*), distal border rounded. Insertion of pelvic fin slightly anterior of vertical through origin of dorsal fin. Inner margin of bases of pelvic fins very close to each other, sometimes in contact. Tip of adpressed pelvic fin extending beyond urogenital and anal openings, but falling short of origin of anal fin. Pelvic splint very thin and slightly shorter than first pelvic-fin ray.

Dorsal-fin rays ii+II $+7\left(17^{*}\right)$, rarely iii $+\mathrm{III}+7$ (1). Base of fin short with distal profile convex. Fin with 8 slender, free basal radials (medial and distal radials fused). Small bony piece fitted in posterior space of distal tip of last basal radial of dorsal fin. Origin of dorsal fin posterior to middle of total length. Tip of first basal radial of dorsal fin immediately posterior to neural spines of 22nd vertebra; tip of its last basal radial immediately anterior to neural spine of 27 th vertebra.

Anal-fin rays ii+II +5 (9), iii+II+5 (9*). Base of fin short. Fin with 6-7 slender and free basal radials. Origin of anal fin slightly anterior to vertical through base of last dorsal fin-ray. Tip of first basal radial of anal fin immediately posterior to hemal spines of 26th vertebra, tip of its last basal radial immediately anterior to hemal spine of 30th-31st vertebrae.

Caudal-fin rays 45 (2), 46 (3), 47 (3), 48 (1), 49 (1), 50 (3). Fin wide, rounded distally, upper lobe slightly longer than lower lobe (Figs. 1-3). Procurrent caudal-fin rays slightly more numerous dorsally, 23 (1), 24 (2), 25 (6), 26 (1), 27 (2), 28 (1), than ventrally, 20 (1), 21 (2), 22 (6), 23 (3), 24 (1). Upper caudalfin lobe with 5 branched rays $\left(18^{*}\right)$; lower caudal-fin lobe usually with 6 branched rays $\left(17^{*}\right)$, rarely $5(1)$. Specimens $29.6 \mathrm{~mm} \mathrm{SL}$ or smaller with branched caudal-fin rays splitting once; specimens $30.7 \mathrm{~mm}$ SL or larger typically with medial rays of caudal fin branched twice. Parhypural and hypurals 1 and 2 co-ossified and jointly bearing 7 rays. Hypural 3 autogenous, with 3 rays. Hypural 4 and 5 totally fused to each other, and jointly bearing 3 rays. Hypurapophysis and secondary hypurapophysis fused to form horizontal and shallow shelf extending to hypural 1, complex hypurapophysis (hypurapophysis "type B" of Lundberg \& Baskin, 1969). Epural and opistural cartilage absent.

Total vertebrae count 42. Pleural ribs 14-15. First pleural rib straight and much thicker than second rib. First complete hemal spine on 20th-21st vertebra.

Head sensory canals with simple (non-dendritic) tubes ending in single pores (Figs. 4-5). Supraorbital sensory canal continuous and connected to optic and infraorbital sensory canals posteriorly. Supraorbital sensory canal bearing 3 branches and pores s1, s3, and s6 (epiphyseal branch and pore). S2, s4, s5, s7, and s8 (parietal) branches and pores absent. Otic sensory canal short, without pores, and continuous with posterior limits of supra- and infraorbital sensory canals, anteriorly, and with anterior limit of postotic sensory canal, posteriorly. Postotic (or temporal) sensory canal extends from posterior limit of otic sensory canals to anterior limit of lateral line, bearing 2 branches and pores (po1 and po2). Infraorbital sensory canal with 2 segments, anterior with 2 branches and pores (i1 and i3) and posterior segment with 2 branches and pores (i10 and i11). Preoperculomandibular sensory canal absent. Lateral-line canal very short, with 2 pores, extending from posteriormost region of opercle to above middle of pectoral fin. Conspicuous rostral line of neuromasts surrounding anterior limit of anterior nostril. Interrupted line of superficial neuromasts along midlateral portion of trunk, from above pectoral fin-base to caudal-fin base, visible in some specimens.

Color. Ground color of dorsal part of head and body pale yellow to orange yellow from mouth to base of tail, mottled with superimposed grayish brown to dark brown medium-sized blotches coalescing irregularly, interspersed with smaller light brown to grayish brown blotches and spots in life (Fig. 3b). 
Pigmentation in 2 skin layers. Lower layer composed of larger horizontally-elongate blotches formed of densely grouped chromatophores. Upper layer composed of smaller blotches and spots formed by loosely arranged chromatophores often overlaying larger blotches (Fig. 4). Trunk with blotches of lower layer generally arranged in 4, irregular, longitudinal, rows (particularly evident in larger specimens): 1 along dorsal region composed of relatively scattered blotches; 1 along dorsolateral region, 1 along midlateral region (most conspicuous), and 1 along ventrolateral region. Each row formed of large, horizontallyelongate, well-defined blotches. Trunk pigmentation interrupted by thin unpigmented lines running along limits of myomeres, particularly visible on ventrolateral region of body. Ground color of head and lateral surface of body as described above, but with blotches and spots less numerous and concentrated than on dorsal portion of body. Barbels light yellow with light brown spots dorsally and whitish ventrally. Ventrolateral surface of head and belly white. Color pattern of juveniles grayish and lighter overall (Fig. 3a).

Dorsal and anal fins light yellow with light to dark brown spots concentrated on rays in life (Figs. 1-4). Caudal fin light yellow to orange yellow with light to dark brown pigmentation concentrated on rays and arranged in interrupted narrow bands in most specimens in life. Dorsal surface of pectoral fin hyaline to light yellow with limited light brown pigmentation basally in smallest specimen in life; pigmentation spreading distally in larger individuals in life, especially along first ray. Pelvic fins hyaline. In alcohol yellow color fades to light tan.

The color pattern alone allows to distinguish the new species from the known species of Trichomycterus from southeastern Brazil outside the T. brasiliensis species-complex: T. concolor Costa has body color mostly uniform, subtly denser on the back and along the midlateral line; T. mirissumba Costa has laterodorsal, lateral, and lateroventral wide and ill-defined bands almost coalescent, composing an almost uniform pattern; T. reinhardti (Eigenmann) has blotches of laterodorsal, lateral, and ventrolateral rows arranged as longitudinal stripes, the lateral one broadest; T. paolence and T. triguttatus have irregularly distributed spots and/or dots, some of them arranged in three faint longitudinal rows; T. variegatus has blotches of deeper layer arranged in four ill-defined stripes, each of them sometimes interrupted and coalesced with the adjacent stripes; and T. zonatus (Eigenmann) has large, irregular blotches arranged in dorsal, laterodorsal, lateral, and ventrolateral rows, vertically coalescent in bars.

Etymology. The specific epithet "maracaya" (also "mbaracaya") is a Tupi-Guarani Amerindian name for the margay wild cat (Leopardus wiedii), an allusion both to the blotched pigmentation pattern of the new species and its predatory habits on vertebrates (tadpoles). A noun in apposition. We propose the English common name Margay pencil catfish for this species.

Distribution. Known only from an unnamed streamlet running along the foothill of the Morro do Ferro, município de Poços de Caldas (Fig. 9), State of Minas Gerais, southeastern Brazil [see Bonotto (1994) for figures of the Morro do Ferro area]. The streamlet is a tributary of the rio Pardo system (upper rio Paraná).

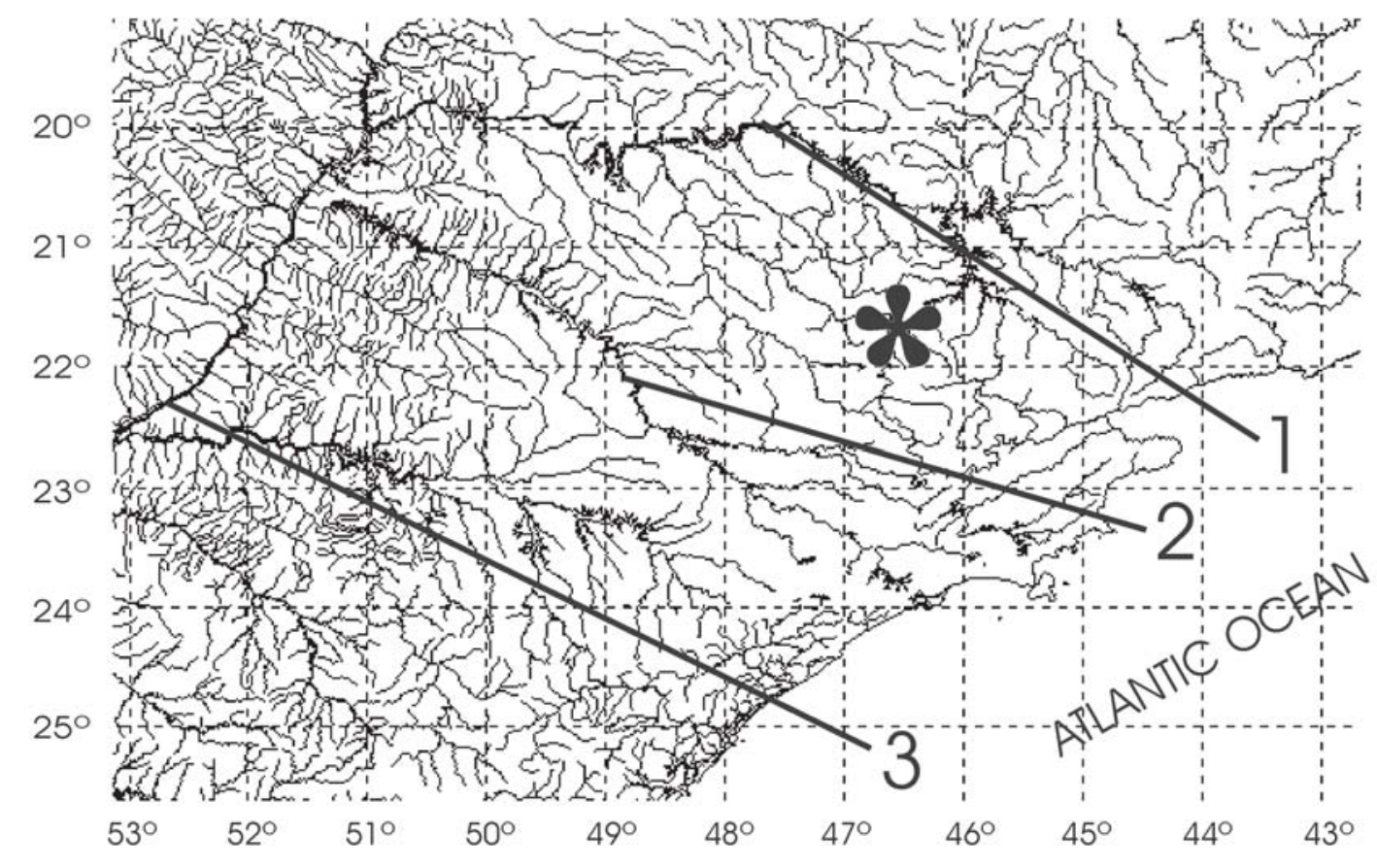

Fig. 9. Map of Southeastern South America with the geographic distribution of Trichomycterus maracaya plotted; 1, rio Grande; 2, rio Tietê; 3, rio Paraná. 


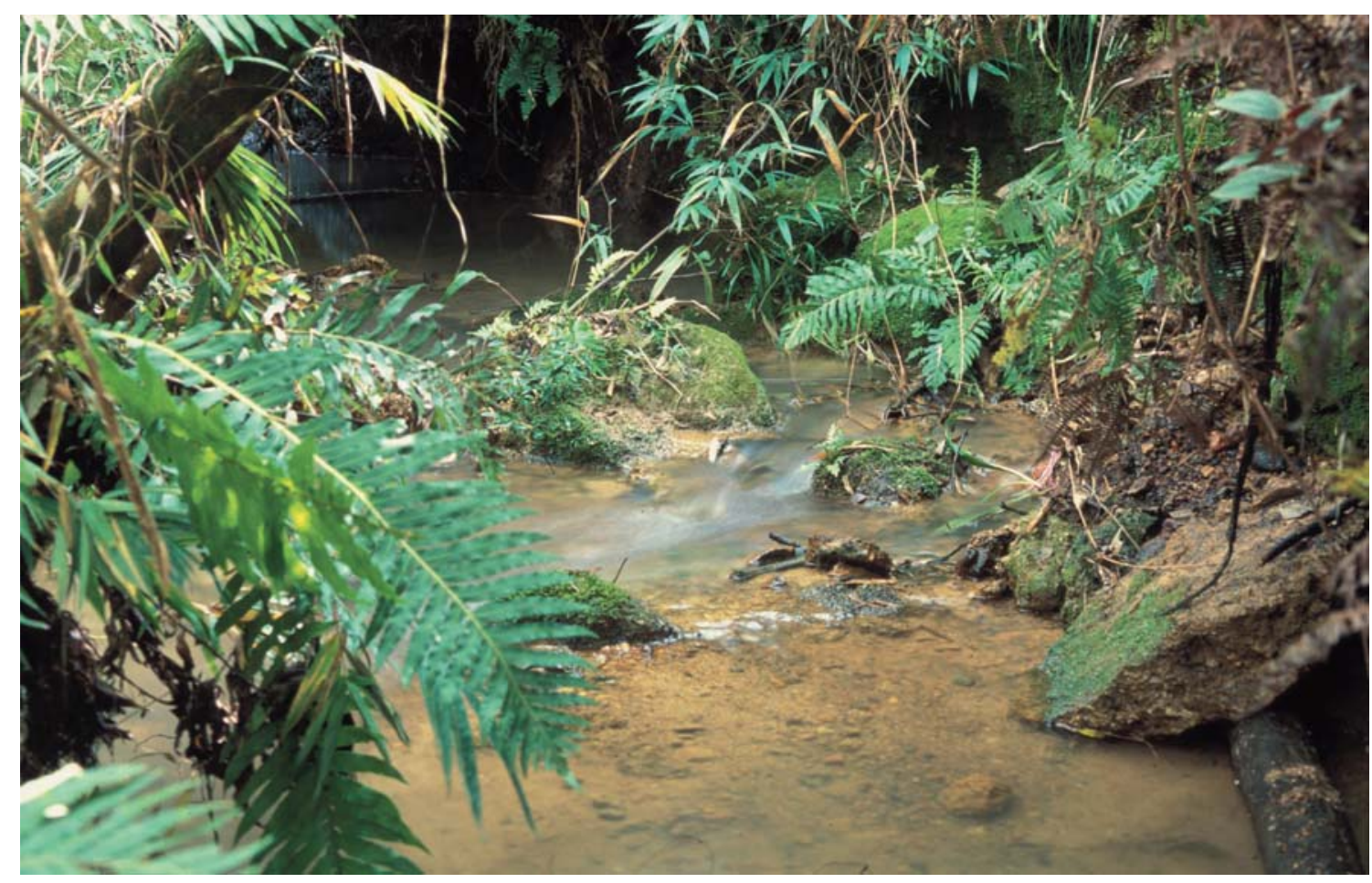

Fig. 10. View of the type locality of Trichomycterus maracaya, a streamlet with limonite bed at the foothill of the Morro do

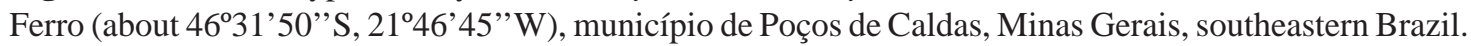

Natural history notes. Trichomycterus maracaya was found along a stretch of about $400 \mathrm{~m}$ of a streamlet $60-210 \mathrm{~cm}$ wide with maximum depth about $140 \mathrm{~cm}$ running through a semi-deciduous gallery forest (Fig. 10). The streamlet runs through a yellowish limonite (iron hydroxide) rocky bed with pebbles and sand, and several pools with muddy bottom and accumulated plant litter and fine sediment. Small individuals (up to $32.5 \mathrm{~mm} \mathrm{SL}$ ) were found among submerged roots near the bank as well as buried in plant litter in small pools $30-50 \mathrm{~cm}$ deep. Larger individuals (up to $51.3 \mathrm{~mm} \mathrm{SL}$ ), in contrast, were found only among plant litter in larger pools up to $100 \mathrm{~cm}$ deep. Trichomycterus maracaya was the only fish species recorded in the streamlet, along with the tadpoles of three species of stream-dwelling frogs. The fishes were active at dawn and night, foraging on the exposed areas of the stream bed and on the leaf litter. One large individual (about $50 \mathrm{~mm} \mathrm{SL}$ ) was observed at early night swallowing tail-first a young, leaf litter-dwelling tadpole of the glass frog Hyalinobatrachium sp. (Centrolenidae). Four other individuals (45.6-51.3 $\mathrm{mm} \mathrm{SL)} \mathrm{regurgitated} \mathrm{young} \mathrm{tadpoles} \mathrm{of} \mathrm{the} \mathrm{same} \mathrm{frog} \mathrm{species}$ upon handling. The regurgitation was digested to differing degrees, an indication that the catfish may prey on tadpoles in the litter throughout the day. In addition to tadpoles, immature benthic aquatic insects (Ephemeroptera, Trichoptera, and Plecoptera) were found among the food regurgitated by these four individuals. Smaller individuals (22.8-33.6 mm TL) had fed on immature benthic aquatic insects, a diet recorded for most Trichomycterus species (e.g., Castro \& Casatti, 1997; de Pinna, 1998; Ferriz, 1998; IS and FAB, pers. obs.).

\section{Discussion}

Few studies have attempted to elucidate the relationships among species of Trichomycterus (e.g., Costa, 1992; Barbosa \& Costa, 2003). This is mostly due to the enormous specific diversity of this genus in conjunction with the difficulty of finding unequivocal intrageneric synapomorphies. We may, however, advance a hypothesis as to the possible phylogenetic affinities of T. maracaya based on body coloration, osteology, and meristics.

Trichomycterus maracaya shares with at least T. brasiliensis, T. iheringi, T. mimonha, T. potschi, T. vermiculatus, and several undescribed similar species from the endemism regions of the upper rio Paraná (Castro \& Casatti, 1997: 345, plate 2, fig. C), upper rio São Francisco, and from the Paraíba do Sul and Ribeira do Iguape river basins, one putative derived character of body coloration. Several species of Trichomycterus display a twolayer pattern of pigmentation, a chromatophore distribution type first described by de Pinna (1992a) for T. castroi de Pinna. The deeper layer of pigmentation is usually composed of larger blotches and spots, formed by densely grouped chromatophores. In the T. brasiliensis species-complex chromatophores of the superficial layer are gradually denser and organized in welldefined patches in progressively larger specimens (Fig. 11a-b). In larger specimens of this species-complex, the coverage of these superficial chromatophores groups is so intense that, associated to the very thick layer of mucus, hides almost completely the blotches of the lower layer (Fig. 11b). These are hardly visible and sometimes are perceptible only as bluish 


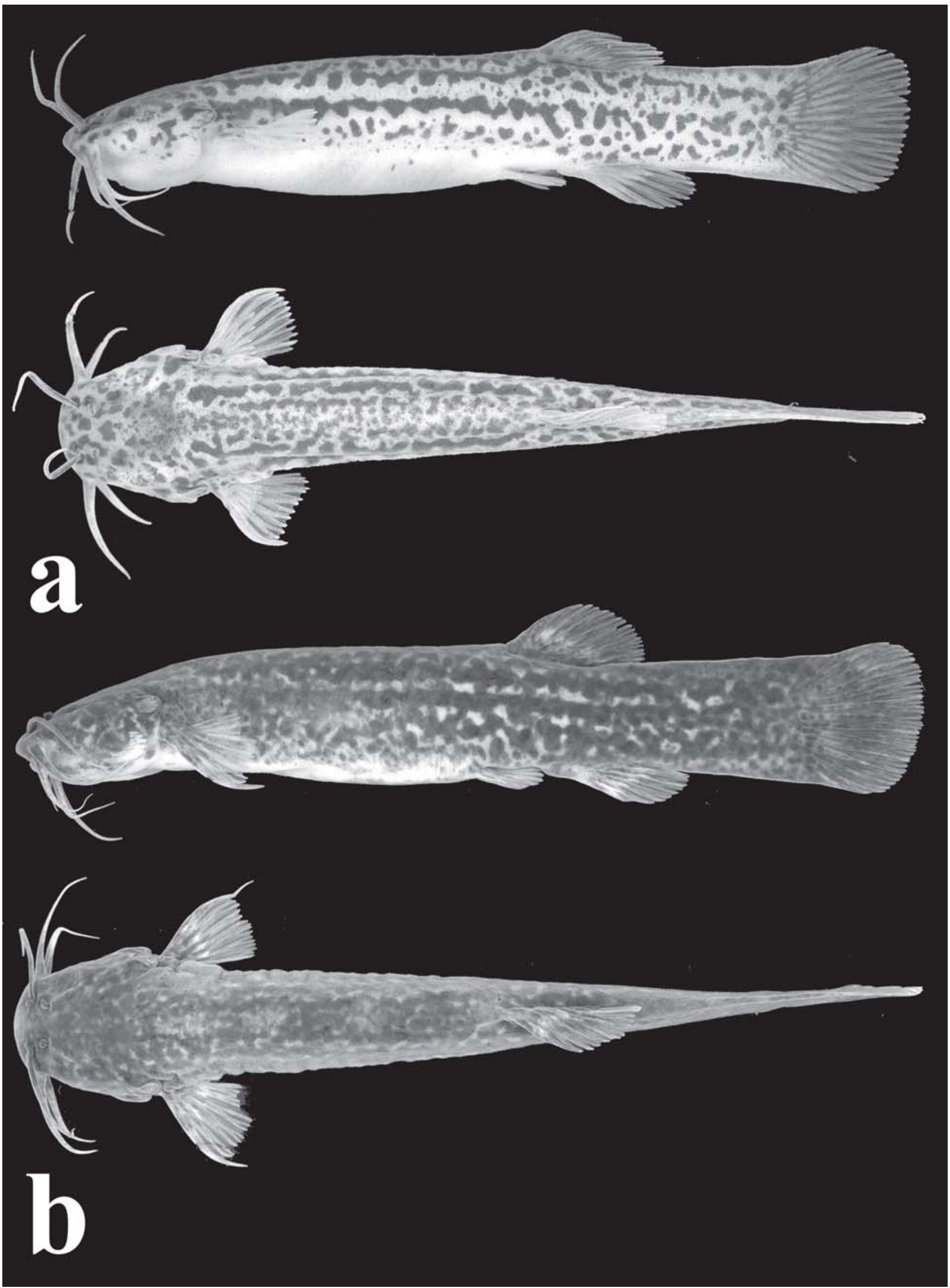

Fig. 11. Trichomycterus sp. of the T. brasiliensis species-complex (LIRP 818), Brazil: São Paulo: município de Cássia dos Coqueiros, ribeirão da Boiada, rio Pardo basin ( $21^{\circ} 17^{\prime} 40^{\prime \prime}$ S 47 $\left.08^{\prime} 49^{\prime \prime} \mathrm{W}\right)$. a, juvenile, $32.8 \mathrm{~mm}$ SL; b, presumed adult, $60.4 \mathrm{~mm}$ SL. 
longitudinal bands, this being the case of, at least, $T$. brasiliensis (cf. Lütken, 1875: pl. 3, fig. 8), T. mimonha (cf. Costa, 1992: 106, fig. 7), T. vermiculatus (FAB \& IS, pers. obs.), and several undescribed species (see Comparative material). In contrast, the presumed adults of T. maracaya conserve the same pattern of the superficial layer of pigmentation as seen in juveniles, with scattered chromatophores only. Notwithstanding the presence of this pattern of deeper layer of pigmentation on the trunk, the species herein assigned to the $T$. brasiliensis species-complex (including T. maracaya) are distinguished in having well defined rows composed of well-delimited dark blotches (Figs. 1-4, and 11), rather than being diffused, as seen in other species of Trichomycterus. These blotches are usually arranged in four irregular longitudinal rows on each half of the trunk: one dorsal, one laterodorsal, one lateral, and one lateroventral. Blotches on trunk arranged in four longitudinal rows may be plesiomorphic within Trichomycteridae, since this character is present in the sister group of the family, the Nematogenyidae [Nematogenys inermis (Guichenot)] and in the most basal members of family (e.g., Copionodon pecten de Pinna), being widespread among trichomycterines [e.g., T. albinotatus Costa, T. alternatus (Eigenmann), T. auroguttatus Costa, T. bahianus Costa, T. brasiliensis, T. iheringi, T. longibarbatus Costa, T. maracaya, T. potschi, T. reinhardti, T. variegatus Costa, and T. zonatus]. The blotches of each row may sometimes coalesce, forming a well-defined (e.g., T. itatiayae Miranda-Ribeiro, T. reinhardti, and T. variegatus) or an interrupted longitudinal stripe (e.g., T. albinotatus, T. alternatus, and T. variegatus), or may fuse vertically with blotches of adjacent rows [e.g., T. auroguttatus, T. florense (Miranda-Ribeiro), and T. zonatus]. The condition in the basal genus Trichogenes Britski \& Ortega seems to be somewhat different, the lateral row lacking, one row of blotches above and another below the lateral line instead (but see variations of this pattern in Sazima, 2004).

The low number of pectoral-fin rays is another possible synapomorphy for the T. brasiliensis species-complex. Pectoralfin ray number is apparently a conservative feature within the Trichomycterinae (FAB \& IS, pers. obs.). Trichomycterus maracaya, along with $T$. brasiliensis, T. iheringi, T. mimonha, $T$. potschi, and T. vermiculatus, as well as the undescribed forms herein assigned to the T. brasiliensis species-complex, have I+56 pectoral-fin rays (Eigenmann, 1918; Costa, 1992; FAB \& IS, pers. obs.) whereas most species of Trichomycterus have higher counts, usually I+7 (e.g. T. albinotatus, T. alternatus, T. auroguttatus, T. bahianus, T. castroi, T. concolor, T. florense, $T$. itatiayae, T. longibarbatus, and T. variegatus) or I+8 [T. immaculatus (Eigenmann \& Eigenmann) and T. nigricans, the type species of Trichomycterus)] (Costa, 1992; de Pinna, 1992a; Arratia, 1998; FAB \& IS, pers. obs.). Members of the basal subfamilies in Trichomycteridae (Copionodontinae and Trichogeninae) have I+10-12 rays (Britski \& Ortega, 1983; de Pinna, 1992b; FAB \& IS, pers. obs.). Therefore, the I+5-6 pectoralfin rays, in the $T$. brasiliensis species-complex, is considered herein as a derived state. A reduced number of pectoral-fin rays also occurs in a few species of Trichomycterus apparently not closely related to the $T$. brasiliensis species-complex: $T$. mirissumba (Costa, 1992; FAB \& IS, pers. obs.), with I+6, as well as $T$. candidus (Miranda-Ribeiro) and T. reinhardti, with I+4-5 (Eigenmann, 1918, FAB \& IS, pers. obs.). This reduction may be either a homoplasy for that species-complex and those species or a synapomorphy for all these taxa.

One osteological feature also apparently corroborates the monophyly of the T. brasiliensis species-complex, or to define a subclade within it, including T. maracaya. Primitively, the epiphyseal bar of adult trichomycterids (and siluriforms) is formed by a bony projection of frontal, which sutures to its counterpart medially, separating the anterior and posterior cranial fontanels ( $c f$. figures in Baskin, 1973; Arratia et al., 1978, Arratia, 1998). This ossified bridge develops ontogenetically from a cartilaginous bar. The larger specimens of $T$. maracaya (43.9 mm SL), T. brasiliensis (LIRP 1968, $83.8 \mathrm{~mm}$ SL), and Trichomycterus sp. (LIRP 645, $48.0 \mathrm{~mm} \mathrm{SL}$ ), have rudimentary bony projections of the frontals, without medial contact (Fig. 5). Thus, the primordial epiphyseal cartilaginous bar separates the anterior and posterior cranial fontanels. This paedomorphic character is apparently derived. An illustration of the cranium of a $45.5 \mathrm{~mm}$ SL specimen of T. potschi (Barbosa $\&$ Costa, 2003: 284, fig. 5), a putative member of this species complex, shows an incomplete epiphyseal bar. However, the distribution of this character within the T. brasiliensis speciescomplex deserves further investigation since it seems to be variable among these species (M. C. C. de Pinna, pers. comm.).

The T. brasiliensis species-complex was formerly diagnosed by having pelvic fins almost contacting each other at their bases rather than distinctly separated, rounded distal border of caudal fin, and irregular, confluent marks on lateral surface of body (Costa, 1992). Thus diagnosed it would comprise at least $T$. brasiliensis, $T$. mimonha, T. mirissumba, T. reinhardti, and T. vermiculatus (Costa, 1992). Fernández \& Vari (2000) regarded some of these characters as synapomorphies that unite $T$. brasiliensis in a monophyletic assemblage with some other southeastern Brazilian species of Trichomycterus, although Costa (1992) called attention to the problematic nature of this latter grouping. Two species assigned by Costa (1992) to this assemblage, T. mirissumba and T. reinhardti, do not belong to the $T$. brasiliensis species-complex as herein recognized (see below). Three of the other species originally assigned to that group, T. amazonicus Steindachner, T. herberti Miranda-Ribeiro, and T. proops Miranda-Ribeiro, are presently assigned to the genus Ituglanis (Costa \& Bockmann, 1993). The distance between pelvic-fin bases appears to be additional information to corroborate the monophyly of $T$. brasiliensis species-complex. The bases of pelvic fins of $T$. brasiliensis, $T$. maracaya, T. mimonha, T. vermiculatus, and of several undescribed species of the T. brasiliensis species-complex, are indeed close to each other, sometimes in contact. This state, considered here as derived, is definitively different from that seen at least in T. alternatus, T. auroguttatus, T. variegatus, and T. zonatus, in which the bases of the pelvic fins are distinctly spaced from each other. This latter state is probably plesiomorphic, since the Nematogenyidae, the sister group of Trichomycteridae, and the basal trichomycterid subfamilies Copionodontinae and Trichogeninae display pelvic fins very spaced from each other 
(FAB \& IS, pers. obs.). Trichomycterus iheringi, a species assigned to the $T$. brasiliensis species-complex, has the pelvic-fin bases well spaced, which may be either a plesiomorphic state or a reversion. The second diagnostic character proposed by Costa (1992), a rounded distal border of caudal fin, is highly variable within the members of this species complex, and the third character, body flanks with irregular confluent marks, probably correspond to the presence of the four discrete longitudinal rows that characterizes the $T$. brasiliensis species-complex.

Table 1. Morphometrics of Trichomycterus maracaya (holotype: ZUEC 6137; paratypes: LIRP 4381, MCP 34575, MNRJ 25872, MZUSP 83357, and ZUEC 4115 and 6136). Values 1 through 24 are percents of standard length; values 25 through 34 are percents of head length.

\begin{tabular}{|c|c|c|c|c|c|}
\hline & Holot. & Range & Mean & SD & $\mathrm{N}$ \\
\hline Total length (mm) & 58.8 & $33.5-61.4$ & - & - & 18 \\
\hline Standard length (mm) & 48.8 & $22.8-51.3$ & - & - & 18 \\
\hline 1.Predorsal length & 65.1 & $61.2-66.0$ & 63.6 & 1.8 & 18 \\
\hline 2.Preanal length & 73.8 & $69.1-73.8$ & 70.9 & 1.6 & 18 \\
\hline 3.Prepelvic length & 62.6 & $56.4-62.6$ & 60.0 & 1.5 & 18 \\
\hline 4.Length of caudal peduncle & 18.0 & $17.3-20.9$ & 19.6 & 1.1 & 18 \\
\hline 5.Depth of caudal-peduncle & 10.7 & $8.6-11.8$ & 10.4 & 0.9 & 18 \\
\hline 6.Anal-fin base length & 9.9 & $8.6-12.6$ & 10.0 & 1.1 & 18 \\
\hline $\begin{array}{l}\text { 7.Length of first unbranched and } \\
\text { segmented dorsal-fin ray }\end{array}$ & 10.2 & $8.5-11.9$ & 10.5 & 1.0 & 18 \\
\hline $\begin{array}{l}\text { 8.Length of second unbranched and } \\
\text { segmented dorsal-fin ray }\end{array}$ & 13.0 & $11.9-14.7$ & 13.9 & 0.8 & 18 \\
\hline $\begin{array}{l}\text { 9.Length of first branched dorsal-fin } \\
\text { ray }\end{array}$ & 15.6 & $13.7-15.9$ & 15.0 & 0.7 & 18 \\
\hline $\begin{array}{l}\text { 10.Length of second branched } \\
\text { dorsal-fin ray }\end{array}$ & 15.2 & $12.6-16.6$ & 14.8 & 0.9 & 18 \\
\hline 11.Dorsal-fin base length & 11.5 & $10.6-13.2$ & 11.8 & 0.7 & 18 \\
\hline $\begin{array}{l}\text { 12.Length of first pectoral-fin ray } \\
\text { (unbranched) }\end{array}$ & 20.7 & $16.3-22.2$ & 19.8 & 1.4 & 18 \\
\hline $\begin{array}{l}\text { 13.Length of second pectoral-fin ray } \\
\text { (first branched) }\end{array}$ & 15.1 & $13.4-16.4$ & 15.2 & 0.8 & 18 \\
\hline $\begin{array}{l}\text { 14.Length of third pectoral-fin ray } \\
\text { (second branched) }\end{array}$ & 13.9 & $12.6-15.9$ & 14.5 & 0.9 & 18 \\
\hline $\begin{array}{l}\text { 15.Length of first pelvic-fin ray } \\
\text { (unbranched) }\end{array}$ & 8.5 & $7.6-9.1$ & 8.4 & 0.4 & 18 \\
\hline $\begin{array}{l}\text { 16.Length of second pelvic-fin ray } \\
\text { (first branched) }\end{array}$ & 9.4 & $8.1-10.1$ & 9.3 & 0.5 & 18 \\
\hline $\begin{array}{l}\text { 17.Length of third pelvic-fin ray } \\
\text { (second branched) }\end{array}$ & 9.5 & $7.9-10.1$ & 9.1 & 0.6 & 18 \\
\hline 18.Body depth & 17.7 & $15.4-20.6$ & 17.6 & 1.3 & 18 \\
\hline 19.Body width & 10.8 & $7.7-10.8$ & 9.3 & 0.8 & 18 \\
\hline 20.Cleithral width & 17.2 & $17.2-20.0$ & 18.3 & 0.8 & 18 \\
\hline 21.Nasal barbel length & 19.1 & $17.1-20.9$ & 19.2 & 1.1 & 18 \\
\hline 22.Maxillary barbel length & 21.7 & $19.6-24.9$ & 22.4 & 1.5 & 17 \\
\hline 23.Rictal barbel length & 17.9 & $16.2-22.8$ & 18.2 & 1.6 & 18 \\
\hline 24.Head length & 21.5 & $20.5-23.3$ & 21.9 & 0.8 & 18 \\
\hline 25.Head depth & 56.7 & $53.9-64.2$ & 55.7 & 3.6 & 18 \\
\hline 26. Head width & 90.1 & $84.0-94.4$ & 90.3 & 2.5 & 18 \\
\hline 27.Interorbital width & 31.2 & $31.0-37.0$ & 33.5 & 1.9 & 18 \\
\hline 28.Eye diameter & 10.5 & $10.5-13.8$ & 11.7 & 0.9 & 18 \\
\hline 29.Snout length & 44.3 & $38.4-46.6$ & 43.0 & 2.4 & 18 \\
\hline $\begin{array}{l}\text { 30.Distance between snout tip and } \\
\text { posterior nare }\end{array}$ & 27.7 & $21.4-30.3$ & 26.4 & 2.5 & 18 \\
\hline 31.Intranarial length & 7.2 & $5.2-8.0$ & 6.7 & 0.8 & 18 \\
\hline 32.Anterior internarial width & 19.3 & $17.9-21.6$ & 19.7 & 1.0 & 18 \\
\hline 33.Posterior internarial width & 18.1 & $17.5-21.0$ & 18.9 & 1.1 & 18 \\
\hline 34.Mouth breadth & 49.5 & $41.4-52.8$ & 46.1 & 3.1 & 18 \\
\hline
\end{tabular}

Recently Barbosa \& Costa (2003) re-diagnosed the $T$. brasiliensis species-complex, based on the following three new morphometric synapomorphies: slender posterior tip of posterior ceratohyal, depth $2.3 \%-6.5 \%$ of longitudinal length of the hyoid bar (vs. 7.6-21.5\%); absent or vestigial posteroventral process of posterior ceratohyal $1.7 \%$ or less of the longitudinal length of the hyoid bar ( $v s$. process always present, 2.6-9.0\%); and slender opercular patch of odontodes, depth $44.0-73.7 \%$ of base length of the opercular dorsal projection ( $v s .81 .5-128.1 \%)$. The species composition of this complex would be, with the exclusion of $T$. reinhardti (and those species currently assigned to Ituglanis), those previously mentioned by Costa (1992). We have found the features proposed by Barbosa \& Costa (2003) to be inapplicable since lack of precise landmarks for the measurements rendered the morphometric comparisons imprecise. Furthermore, comparisons of the posterior ceratohyal and opercle of T. potschi (Barbosa \& Costa, 2003: 283-284, figs. 3-4) with the same elements of T. maracaya (Figs. 6-7) and other species of the T. brasiliensis species-complex as diagnosed here revealed no differences.

Due to its overall color pattern and occurrence in the upper rio Paraná, the species herein described as Trichomycterus maracaya may be mistakenly identified as T. brasiliensis, a species described from the rio São Francisco basin (Lütken, 1875) and also reported from the upper rio Paraná (e.g., Castro \& Casatti, 1997). Specimens usually identified as T. brasiliensis from the rio Paraná basin probably represent a complex of similar species difficult to diagnose, a common trend for this speciesrich genus (de Pinna, 1998). However, two features distinguish the new species from other species of the T. brasiliensis speciescomplex. Juveniles of most, if not all, species of the T. brasiliensis species-complex have the blotches of the row of the inner layer on the lateral region of trunk close to each other, more so on the anterior part of trunk (Fig. 11a). These blotches sometimes form a lateral stripe, which progressively split into blotches in larger specimens (Fig. 11a; see also Castro \& Casatti, 1997: 345, plate 2, fig. C; and Casatti \& Castro, 1998: 235, fig. 4C). This change is accompanied by the appearance of additional blotches over the body, distributed approximately along the four main longitudinal blotch rows. In T. brasiliensis speciescomplex, this is the case at least of T. brasiliensis ( $c f$. Lütken, 1875: pl. 3, fig. 8), T. iheringi (FAB \& IS, pers. obs.), T. mimonha (Costa, 1992: 106, fig. 7), T. vermiculatus (FAB \& IS, pers. obs.), and several undescribed species (see Comparative Material). In contrast, the lateral row of T. maracaya, although the most conspicuous one, does not form an evident stripe at any developmental stage (the blotches progressively coalesce to form more densely arranged rows, see Figs. 1-2). Therefore, the lateral stripe may be regarded as a plesiomorphic trait since it is shared by juveniles of very distinct and seemingly unrelated species of the Trichomycteridae, such as Copionodon pecten, T. alternatus, and T. brasiliensis (FAB \& IS, pers. obs.). Adults of some species such as T. itatiayae ( $c f$. Caramaschi \& Caramaschi, 1991: 223, fig. 1; FAB \& IS, pers. obs.) and $T$. reinhardti (FAB \& IS, pers. obs.) retain the lateral stripe without notable changes, an additional indication that this color pattern may be a basal trait within Trichomycterinae. 
Arratia et al. (1978) reported a remarkable intraspecific variation of body pigmentation for Trichomycterus mendozensis Arratia, Chang, Menu-Marque \& Rojas (= Silvinichthys mendozensis; Arratia, 1998). However, this variation seems to be a highly unusual condition within Trichomycteridae, since the inspection of ontogenetic series of several species, especially of Trichomycterus, has shown that the pattern despite being different between species, displays a highly conservative change pattern. As mentioned before, specimens between $24.1 \mathrm{~mm} \mathrm{SL}$ and $51.3 \mathrm{~mm}$ SL of T. maracaya display no conspicuous changes in body coloration pattern, notwithstanding the fact that this latter species and other members of the $T$. brasiliensis speciescomplex have four rows of blotches along the trunk in juveniles (Figs. 2 and 11a). We suggest that ontogenetic and heterochronic studies on the development of body pigmentation of Trichomycterus species may prove an additional, useful tool to elucidate their phylogenetic relationships.

Comparative material. Nematogenys inermis: LBP 1002, 262.0$74.6 \mathrm{~mm}$ SL; Chile: Estero Aguas de la Gloria. Copionodon pecten: LIRP 1012, 26, 19.3-56.3 mm SL, 2 c\&s, 43.8-48.1 mm SL; LIRP 1013, 12, 31.9-40.7 mm SL; Brazil: Bahia: rio Paraguaçu basin. Trichogenes longipinnis Britski \& Ortega: LIRP 1023, 3, 37.0-44.5 mm SL; LIRP 1058, 4, 39.3-48.5 mm SL; LIRP 1059, 9, 29.0-73.8 mm SL, 1 c\&s, 47.4 mm SL; Brazil: São Paulo: southeastern coastal area. Trichomycterus albinotatus: LIRP 4333, 3, 23.9-36.1 mm SL, 1 c\&s, 31.7 mm SL; Brazil: Rio de Janeiro: rio Paraíba do Sul basin. Trichomycterus alternatus: LIRP 28, 1,32.9 mm SL; LIRP 266, 1, 43.7 mm SL; Brazil: Minas Gerais: rio Doce basin. Trichomycterus auroguttatus: LIRP 4334, 3, 37.9-92.3 mm SL, 1 c\&s, 59.3 mm SL; Brazil: Rio de Janeiro: rio Paraíba do Sul basin. Trichomycterus brasiliensis: LIRP 1968, 12, 32.3-126.4 mm SL, 2 c\&s, 68.0-83.8 mm SL; Brazil: Minas Gerais, rio São Francisco basin. Trichomycterus candidus: LIRP 815, 2, 17.3-30.9 mm SL; LIRP 1098, 1, 32.5 mm SL; Brazil: Minas Gerais: rio Grande basin. Trichomycterus castroi: MZUSP 36964, holotype, 118.3 mm SL; MZUSP 36965, paratype, $121.8 \mathrm{~mm}$ SL; Brazil: Paraná, rio Iguaçu basin; MZUSP 36965, paratype, 121.8 mm SL; Brazil: Paraná, rio Iguaçu basin. Trichomycterus concolor: MZUSP 43347, holotype, 63.2 mm SL; Brazil: Minas Gerais, rio São Francisco basin. Trichomycterus cubataonis Bizerril: MNRJ 12490, holotype, $47.1 \mathrm{~mm}$ SL; Brazil: Santa Catarina, rio Cubatão basin. Trichomycterus davisi (Haseman): LIRP 2798, 18, 25.0-82.4 mm SL; LIRP 2799, 31, 16.7-85.3 mm SL, 2c\&s, 44.2-74.9 mm SL; LIRP 2800, 1, 48.6 mm SL; Brazil: São Paulo, rio Paranapanema basin; MZUSP 79588, 10, 36.6-64.5 mm SL; Brazil: Paraná, rio Ribeira do Iguape basin. Trichomycterus florense: MNRJ 23991, 1, 73.2 mm SL; Brazil: São Paulo, rio Paraíba do Sul basin. Trichomycterus iheringi: LIRP 1027, 1, 75.9 mm SL; LIRP 1055, 4, 76.8-87.5 mm SL, 1 c\&s, $77.1 \mathrm{~mm} \mathrm{SL;}$ LIRP 3183, 2, 72.6-88.0 mm SL; LIRP 3185, 1, 42.9 mm SL; Brazil: São Paulo, rio Ribeira de Iguape basin. Trichomycterus immaculatus: LIRP 285, 28, 31.9-102.7 mm SL, 2 c\&s, 74.0-76.2 mm SL; Brazil: Minas Gerais: rio Doce basin. Trichomycterus itatiayae: MNRJ 20049, 1, 78.1 mm SL;ZUEC 2076, 1, $27.6 \mathrm{~mm}$
SL;ZUEC 5558, 2, 54-7-54.8 mm SL;ZUEC 6234, 1, 85.6 mm SL; Brazil: Rio de Janeiro, Parque Nacional de Itatiaia. Trichomycterus longibarbatus: MZUSP 43339, holotype, $58.6 \mathrm{~mm}$ SL; Brazil: Espírito Santo, rio Reis Magos basin. Trichomycterus mimonha: MZUSP 43343, holotype, 56.8 mm SL; MZUSP 43344, paratypes, 6, 22.0-74.2 mm SL; Brazil: São Paulo, rio Paraíba do Sul basin. Trichomycterus mirissumba: MZUSP 43345, holotype, $56.8 \mathrm{~mm}$ SL; MZUSP 43346, paratypes, 3, 27.2-51.4 mm SL; LIRP 4335, 1, 55.4 mm SL, 1 c\&s, 56.3 mm SL; Brazil: Rio de Janeiro, rio Paraíba do Sul basin. Trichomycterus reinhardti: LIRP 1062, 2, 30.7-38.1 mm SL, 1 c\&s, 30.5 mm SL; Brazil: Minas Gerais, rio Grande basin. Trichomycterus variegatus: LIRP 647, 189, 19.6-53.8 mm SL, 2 c\&s, 51.4-54.6 mm SL; LIRP 3457, 3, 44.6-49.0 mm SL: Brazil: Minas Gerais: rio São Francisco basin. Trichomycterus cf. variegatus: LIRP 616, 1, 40.5 mm SL; Brazil: Minas Gerais: rio Grande basin. Trichomycterus zonatus: LIRP 596, 8, 20.9-69.8 mm SL; Brazil: Rio de Janeiro, rio Paraíba do Sul basin. Trichomycterus spp. (T. brasiliensis species-complex): LIRP 645, 32, 28.1-81.3 mm SL, 2 c\&s, 48.0-60.0 mm SL; Brazil: Minas Gerais: rio São Francisco basin. LIRP 611, 1, 49.0 mm SL; Brazil: Minas Gerais: rio Grande basin. LIRP 14, 12, 28.4-62.1 mm SL;LIRP 27, 5, 35.7-99.2 mm SL;LIRP 39, 2, 18.5-29.9 mm SL;LIRP 177, 7, 35.5-63.0 mm SL; LIRP 180, 1,32.5 mm SL;LIRP 190, 1,30.6 mm SL; LIRP 232, 1, 29.1 mm SL; LIRP 818, 19, 16.661.8 mm SL, 2 c\&s, 40.1-57.0 mm SL; Brazil: São Paulo, rio Pardo basin. LIRP 2802, 40, 33.8-148.8 mm SL; Brazil: São Paulo: rio Piracicaba basin. LIRP 1935, 1, 44.2 mm SL; LIRP 1984, 7, 22.443.9 mm SL; Brazil: São Paulo, rio Sapucaí basin.

\section{Acknowledgements}

We thank Arion Aranda, Paulo A. Buckup, Gustavo W. Nunan, Claudio de Oliveira, Osvaldo T. Oyakawa, and Mário C. C. de Pinna for allowing the examination of specimens under their care; Célio F. B. Haddad for help in the fieldwork; Alexandre C. Ribeiro and Marlies Sazima for helping with the photographs; Marcelo R. de Carvalho, Richard P. Vari, and two anonymous reviewers, for critically reading the manuscript; and the $\mathrm{CNPq}(300992 / 79)$ and FAPESP (00/12339-2) for financial support. This paper is part of the PRONEX Project "Conhecimento, conservação e utilização racional da biodiversidade de peixes do Brasil" (FINEP/CNPq, No. 661058/1997-2) and the "All Catfish Species Inventory” Project (NSF DEB-0315963).

\section{Literature Cited}

Arratia, G. 1998. Silvinichthys, a new genus of trichomycterid catfishes from the Argentinian Andes, with redescription of Trichomycterus nigricans. Ichthyological Exploration of Freshwaters, 9 (4): 347-370.

Arratia, G., A. Chang, S. Menu-Marque \& G. Rojas. 1978. About Bullockia gen. nov., Trichomycterus mendozensis n. sp. and revision of the family Trichomycteridae (Pisces, Siluriformes). Studies on Neotropical Fauna and Environment, 13 (3/4): 157-194. 
Arratia, G. \& L. Huaquin. 1995. Morphology of the lateral line system and of the skin of diplomystid and certain primitive loricarioid catfishes and systematic and ecological considerations. Bonner Zoologische Monographien, 36: 1-110.

Barbosa, M. A. \& W. J. E. M. Costa. 2003. Trichomycterus potschi (Siluriformes: Loricarioidei): a new trichomycterid catfish from coastal streams of southeastern Brazil. Ichthyological Exploration of Freshwaters, 14 (3): 281-287.

Baskin, J. N. 1973. Structure and relationships of the Trichomycteridae. Unpublished Ph.D. Dissertation, City University of New York, New York. 389p.

Bizerril, C. R. S. F. 1994. Descrição de uma nova espécie de Trichomycterus (Siluroidei, Trichomycteridae) do Estado de Santa Catarina, com uma sinopse da composição da família Trichomycteridae no leste brasileiro. Arquivos de Biologia e Tecnologia, 37 (3): 617-628.

Bonotto, D. M. 1994. Utilização de modelo isotópico de urânio no estudo de aquí́feros do Morro do Ferro, Poços de Caldas (MG). Revista Brasileira de Geociências, 24 (1): 52-59.

Britski, H. A. \& H. Ortega. 1983. Trichogenes longipinnis, novo gênero e espécie de Trichomycteridae do sudeste do Brasil (Pisces, Siluriformes). Revista Brasileira de Zoologia, 1 (3): 211-216.

Britski, H. A., Y. Sato \& A. B. S. Rosa. 1986. Manual de identificação de peixes de região de Três Marias (com chaves de identificação para os peixes da bacia do São Francisco). 2nd Ed. Brasília, Câmara dos Deputados, Coordenação de Publicações, Companhia de Desenvolvimento do Vale do São Francisco. 115p.

Caramaschi, E. P. \& U. M. Caramaschi. 1991. Taxonomic status of the trichomycterid catfish Trichomycterus itatiayae. Copeia, 1991 (1): 222-224.

Casatti, L. \& R. M. C. Castro. 1998. A fish community of the São Francisco River headwaters riffles, southeastern Brazil. Ichthyological Exploration of Freshwaters, 9 (3): 229242.

Castro, R. M. C. \& L. Casatti. 1997. The fish fauna from a small forest stream of the upper Paraná River basin, southeastern Brazil. Ichthyological Exploration of Freshwaters, 7 (4): 337-352.

Castro, R. M. C. \& N. A. Menezes. 1998. Estudo diagnóstico da diversidade de peixes do Estado de São Paulo. Pp. 311. In: Castro, R. M. C. (Ed.). Biodiversidade do Estado de São Paulo, Brasil: síntese do conhecimento ao final do século XX, 6: vertebrados. São Paulo, FAPESP, 71p.

Costa, W. J. E. M. 1992. Description de huit nouvelles espèces du genre Trichomycterus (Siluriformes: Trichomycteridae), du Brésil oriental. Revue Française d'Aquariologie et Herpetologie, 18 (4): 101-110.

Costa, W. J. E. M. \& F. A. Bockmann. 1993. Un nouveau genre néotropical de la famille des Trichomycteridae (Siluriformes: Loricarioidei). Revue Française d'Aquariologie et Herpetologie, 20 (2): 43-46.

Eigenmann, C. H. 1918. The Pygidiidae, a subfamily of South American catfishes. Memoirs of the Carnegie Museum, 7 (5): 259-398.
Fernández, L. \& R. P. Vari. 2000. New species of Trichomycterus (Teleostei: Siluriformes: Trichomycteridae) lacking a pelvic fin and girdle from the Andes of Argentina. Copeia 2000 (4): 990-996.

Ferriz, R. A. 1998. Alimentación de Trichomycterus corduvense Weyenbergh, 1879 (Teleostei: Trichomycteridae) en dos ríos serranos de San Luis, Argentina. Revista del Museo Argentino de Ciencias Naturales "Bernardino Rivadavia", 5 (1): 43-49.

Leviton, A. E., R. H. Gibbs Jr., E. Heal \& C. E. Dawson. 1985. Standards in herpetology and ichthyology. Part 1. Standard symbolic codes for institutional resource collections in herpetology and ichthyology. Copeia, 1985 (3): 802-832.

Lundberg, J. G. \& J. N. Baskin. 1969. The caudal skeleton of the catfishes, Order Siluriformes. American Museum Novitates, 2398: 1-49.

Lütken, C. H. 1875. Velhas-Flodens Fiske. Et Bidrag til Brasiliens Ichthyologi. Kongelige Danske Videnskabernes Selskabs Skriften, 12 (2): 122-252.

Northcutt, G. 1989. The phylogenetic distribution and innervation of craniate mechanoreceptive lateral lines. Pp. 1718. In: Coombs, S. P., P. Görner \& H. Münz (Eds.). The mechanosensory lateral line. New York, Springer.

de Pinna, M. C. C. 1989. A new sarcoglanidine catfish, phylogeny of its subfamily, and an appraisal of the phyletic status of the Trichomycterinae (Teleostei, Trichomycteridae). American Museum Novitates, 2950: 1-25.

de Pinna, M. C. C. 1992a. Trichomycterus castroi, a new species of trichomycterid catfish from the Rio Iguaçu of southeastern Brazil (Teleostei: Siluriformes). Ichthyological Exploration of Freshwaters, 3 (1): 89-95.

de Pinna, M. C. C. 1992b. A new subfamily of Trichomycteridae (Teleostei, Siluriformes), lower loricarioid relationships and a discussion on the impact of additional taxa for phylogenetic analysis. Zoological Journal of the Linnean Society, 106 (3): 175-229.

de Pinna, M. C. C. 1998. Phylogenetic relationships of Neotropical Siluriformes (Teleostei: Ostariophysi): historical overview and synthesis of hypotheses. Pp. 279-330. In: Malabarba, L. R., R. E. Reis, R. P. Vari, Z. M. Lucena \& C. A. S. Lucena (Eds.). Phylogeny and Classification of Neotropical Fishes. Porto Alegre, Edipucrs, 603p.

de Pinna, M. C. C. \& W. B. Wosiacki. 2003. Family Trichomycteridae (Pencil or parasitic catfishes). Pp. 270290. In: Reis, R. E., S. O. Kullander \& C. J. Ferraris, Jr. (Org.). Check List of the Freshwater Fishes of South and Central America. Porto Alegre, Edipucrs, 729p.

Sazima, I. 2004. Natural history of Trichogenes longipinnis, a threatened trichomycterid catfish endemic to Atlantic forest streams in southeast Brazil. Ichthyological Exploration of Freshwaters, 15 (1): 49-60.

Taylor, W. R. \& G. C. Van Dyke. 1985. Revised procedures for staining and clearing small fishes and other vertebrates for bone and cartilage study. Cybium, 9 (2): 107-119.

Received April, 2004 Accepted June, 2004 